\title{
GOOD ENOUGH FOR GOVERNMENT WORK: THE CONSTITUTIONAL DUTY TO PRESERVE FORENSIC INTERVIEWS OF CHILD VICTIMS
}

\author{
LUCY S. MCGOUGH*
}

I

\section{INTRODUCTION}

In a Memphis, Tennessee day-care abuse investigation, police investigators made videotapes of their interviews with young alleged victims. As might be expected, some of the children gave inconsistent accounts. ${ }^{1}$ Quite unexpected, even shocking, is the fact that, after reviewing the interviews, an assistant attorney instructed the investigators to destroy the tapes so that they would not be available for discovery. ${ }^{2}$ No verbatim transcripts were made, and the tapes were reused for other investigations. The Tennessee Supreme Court held that such behavior constituted willful prosecutorial misconduct in violation of Brady v. Maryland, ${ }^{3}$ which requires disclosure of exculpatory evidence, that is, evidence that tends to support a claim of innocence. ${ }^{4}$ In reversing the conviction and remanding for a new trial,

Copyright (C) 2002 by Lucy S. McGough

This article is also available at http://www.law.duke.edu/journals/65LCPMcGough.

* Vinson \& Elkins Professor of Law, Louisiana State University Law School.

Over the years, several research assistants have gathered information for this long-intended scholarship. I am indebted to Kenneth Hooks ('97), Jeff Oglesbee ('98), and Harry Lane ('01) for their help and patience. Our foreign materials specialist, George D. Jacobsen, has provided assistance far beyond the duties of a librarian. Finally, I am grateful for the e-mail conversations with Robert Rosenthal, Esq. See infra note 126.

1. State v. Ballard, 855 S.W.2d 557, 560 (Tenn. 1993).

2. See Tenn. R. CRIM. Pro. 26.2 (2000) (requiring production of statements of witnesses). Even absent express inclusion within a discovery statute, a defendant would urge that he has a constitutional right to access to such a videotape if it contains exculpatory information. In Woods v. State, 713 S.W.2d 173, 174-75 (Tex. App. 1986), the defendant learned that the accusing child witness had been the subject of two videotaped interviews. One interview was incriminating and introduced at trial. The other, an earlier exculpatory tape, showed that the child initially attributed her injuries to a fall from a playground slide rather than to the defendant's assault. Despite the lack of explicit statutory authority, the Texas Court of Appeals properly held that the prosecution had a constitutional obligation to disclose the exculpatory tape to the accused defendant.

3. 373 U.S. 83 (1963). In 1976, the Supreme Court recast the Brady rule as emphasizing disclosure if favorable evidence was material to either guilt or punishment. See United States v. Agurs, 427 U.S. 97, 104 (1976).

4. The Tennessee Supreme Court stated in Ballard, 855 S.W.2d at 560:

It was held [by the Court of Criminal Appeals] that the State may not use witnesses whose initial interviews were taped and intentionally destroyed by the State investigators. The court [of Appeals] held that on trial the trial judge should first conduct a hearing to determine which 
the court barred the use of the children's videotaped interviews as proxy witnesses on retrial. ${ }^{5}$

Any prosecutor concerned with controlling the flow of evidence would quickly appreciate the lesson of this Tennessee case: Destruction of a record is verboten, but if no record is ever made, there is nothing to disclose. Can the Constitution be so easily sidestepped? Is there a constitutional duty cast upon a prosecutor to preserve evidence, that is, to videotape a forensic interview of a child?

This article proceeds with confidence on the premise that a forensic interview of a child by a member of the prosecutorial team offers many opportunities for compromising the reliability of the child's remembered account. A vast volume of research data now exists that documents the conclusion that the forensic interviewing of children is a very delicate, sophisticated, and high-risk enterprise. ${ }^{6}$ Furthermore, there are so many additional advantages from videotaping for the administration of the criminal justice system, far outweighing any suggested disadvantages, that videotaping of forensic interviews of children should become standard operating practice. But, as this article reveals, videotaping is not universally required, and, indeed, off-the-record forensic interviews of children continue to be tolerated as "good enough for government work."

Part II of this article presents a brief overview of the practice of videotaping forensic interviews of child victims. Part III explores the Supreme Court's evidence preservation cases and the contours of the prosecution's duties under the Due Process Clause. Part IV analyzes the nature of forensic interviewing and argues that even under the Court's current narrow interpretation of an accused's entitlements, videotaping is constitutionally mandated by fundamental fairness under the Due Process Clause.

\section{The PRACTICE AND BENEFITS OF VIDEOTAPING}

As the term is used in this article, "forensic" evidence is, to some degree, malleable in that it is evidence that the state can shape, as opposed to prevenient and

witnesses were competent to testify. We are inclined to agree with the view of the lower court

in this regard. Id.

5. Id. at 560, 563. Courts have varied concerning the appropriate remedy for wrongful suppression of evidence. See Morgan v. Gertz, 166 F.3d 1307, 1308-10 (10th Cir. 1999) (reviewing a Colorado court's entry of a directed judgment of acquittal but denying relief because there had been no conviction); United States v. Cooper, 938 F.2d 928, 933 (9th Cir. 1983) (dismissing the indictment or other form of charges); State v. Willits, 393 P.2d 274, $277-79$ (Ariz. 1964) (discussing a jury instruction designed to substitute for missing evidence). See generally United States v. Cooper, 983 F.2d 928 (9th Cir. 1993) (discussing possible remedies).

6. See generally Lucy S. McGough, ChILd Witnesses: FragiLE Voices in the American LEGAL SYSTEM (1994); Stephen J. Ceci \& Richard D. Friedman, The Suggestibility of Children: Scientific Research and Legal Implications, 86 CORNELL L. REV. 33 (2000); Lucy S. McGough \& Amye Warren, Research on Children's Suggestibility: Implications for the Investigative Interview, 23 CRIM. JUST. \& BEHAV. 269 (1996). But see Thomas D. Lyon, The New Wave in Children's Suggestibility Research: A Critique, 84 CORNELL L. REV. 1004 (1999) (arguing that the suggestibility of children is an overrated risk and that government investigators are highly skilled interlocutors). 
fixed evidence that the state has collected. ${ }^{7}$ A forensic interview of a child usually occurs soon after at least one interview has taken place in which the child has alleged abuse. This forensic interview is conducted for the purpose of creating evidence that will be admissible at trial, either as a recording of the interview or as testimony of the interviewer about what transpired during the interview. The salient features of a forensic interview of a child are that the state arranges, directs, and otherwise controls the creation of the evidence; that there is an opportunity for interviewer distortion of the evidence; that once contamination occurs, the distortion may be irreversible; that the state agent (the interviewer) cannot himself produce a faithful alternative record of the myriad interactions that occur during the interview; that the defendant cannot replicate this evidence by any other means; and that this evidence is the most critical and may be the only evidence of proof of the accusation. Each of these factors will be discussed in later portions of this article. The forensic interview of a child is such an important event in any child abuse prosecution that a record of the exchange is essential to an evaluation of the reliability of the key witness and of the sufficiency of any accusation.

Proposals calling for the videotaping of investigative interviews of child abuse victims are no longer novel and are barely innovative. In Scandinavia, videotaping has been the norm for the past forty years. ${ }^{8}$ Since 1991, criminal prosecutions in Great Britain for assaults, batteries, cruelty, and sexual offenses involving children have permitted videotaped forensic interviews of the victims to be admitted into evidence at trial just as would direct testimony from the child on the witness stand. ' Indeed, a pair of reforms consistently recommended by scholars, empiricists, and psychologists is that the initial interview be conducted by a trained professional and that the interview session be videotaped so that other professionals can independently evaluate it..$^{10}$ At least thirty-nine states now explicitly authorize at least some use of videotaped interviews of child victims, although no state as of

7. Webster's defines "forensic" as "used in or suitable to courts of law, public debate, or formal argumentation.” WEBSTER'S NEW WORLD DICTIONARY OF AMERICAN ENGLISH 528 (3rd ed. 1988).

8. See John R. SPENCER \& RHONA H. Flin, The EVIDENCE OF CHILdREN: THE LAW AND The Psychology 166 (1990); David Libai, The Protection of the Child Victim of a Sexual Offense in the Criminal Justice System, 15 WAYNE L. REV. 977 (1969). For a general discussion of the elicitation of children's testimony in other legal systems, see SPENCER \& FLIN at 393-405.

9. Great Britain has recently expanded protection for child witnesses and modified its taping procedures. The statute now provides that victims of sexual abuse are "entitled" to be cross-examined in a pretrial hearing before the court, unless they decline that measure, and, like other child witnesses, opt to postpone cross-examination until trial. All forensic interviews are videotaped. See Criminal Justice Act, ch. 33 (1988) (Eng.) (as amended by the Youth Justice \& Criminal Evidence Act, ch. 29 (1999) (Eng.)). For a discussion of current and former British statutes and practice, see Laura C.H. Hoyzano, Variations on a Theme by Pigot: Special Measures Directions for Child Witnesses, 2000 CRIM. L. REV. 250.

10. See State v. Giles, 772 P.2d 191, 199 (Idaho 1989) (citing expert testimony on videotaped interviews); Home OfFice in CONJUNCTION With THE DePartment of Health, Memorandum of

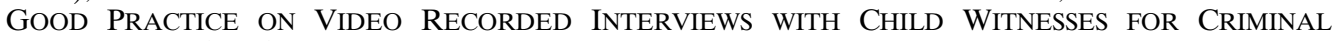
PROCEEDINGS (1992); Michael E. Lamb et al., Making Children into Competent Witnesses: Reactions to the Amicus Brief in In re Michaels, 1 PSYCHOL. PUB. POL'Y \& L. 438, 444-45 (1995). 
yet mandates or provides significant incentives for videotaping forensic interviews. ${ }^{11}$

Several scholars have created laundry lists of the advantages and disadvantages of videotaping, although most conclude with a cautious endorsement of the practice. ${ }^{12}$ My own list is as follows.

\section{A. The Benefits of Videotaping Forensic Interviews}

As a means for ensuring that the trial will result in a fair and accurate determination of guilt, pretrial videotaping should be required because it enhances the reliability of the child's evidence. Research demonstrates that the accuracy of children's memories declines more quickly over time than that of adults. ${ }^{13}$ Videotaping preserves the account while fresh before memories fade and internal and external interferences take place. It minimizes the need for multiple interviews and lessens the possibility of contamination of the child's reminiscences. ${ }^{14}$ Of course, a videotape may be a wasted opportunity unless the investigative interview is conducted by a skilled professional. Those individuals on the sidelinesjudges, lawyers, scholars-should acknowledge that interviewing a child requires a sophisticated set of skills and on-the-spot adaptability. A videotaped forensic interview conducted by a well-trained interviewer captures a more coherent and complete account of the child's experience than any elicited by an untrained prosecutor or defense counsel on cross-examination. ${ }^{15}$

A second benefit, which is of only slightly lesser importance, is the opportunity videotaping provides to enhance the child's credibility. The more relaxed, out-ofcourt process permits the child to recall her or his experiences in an informal, relatively private setting. Moreover, there is empirical evidence that memory is enhanced when children are interviewed in relaxed surroundings. ${ }^{16}$ Videotaping cap-

11. See Nancy Walker Perry \& Bradley D. McAuliff, The Use of Videotaped Child Testimony: Public Policy Implications, 7 NOTRE DAME J. L. ETHICS \& PUB. POL'Y 387, 392-95 (1993). A videotape of a forensic interview of a child can clearly qualify as "past recollection recorded," a traditionally recognized exception to the ban on the receipt of hearsay, even without special novel legislation. Furthermore, a state might also offer an evidentiary bonus, such as a presumption of trustworthiness for a videotaped forensic interview, that meets certain prerequisites for ensuring reliability. See MCGOUGH, supra note 6, at 217-19. The highest courts of several states, notably Florida and Idaho, have strongly urged investigators to videotape child victims' statements. See State v. Townsend, 635 So. 2d 949, 960 (Fla. 1994); State v. Giles, 772 P.2d 191, 195 (Idaho 1990) (Huntley, J., concurring).

12. See John E.B. Myers, Investigative Interviews of Children: Should They Be Videotaped?, 7 NOTRE DAME J. L. ETHICS \& PUB. POL'Y 371 (1993); Nancy Walker Perry \& Bradley D. McAuliff, supra note 11, at 399-405, 420-22. But see Paul Stern, Videotaping Child Interviews: A Detriment to an Accurate Determination of Guilt, 7 J. INTERPERSONAL VIOLENCE 278, 278 (1992) (arguing that routine videotaping of child sexual abuse victims is inappropriate and dangerous).

13. Rhona Flin et al., The Effect of a Five-Month Delay on Children's and Adults' Eyewitness Memory, 83 BRIT. J. PSYCHOL. 323, 333 (1992).

14. Debra A. Poole \& Lawrence T. White, Two Years Later: Effects of Question Repetition and Retention Interval on the Eyewitness Testimony of Children and Adults, 29 DEV. PSYCHOL. 844, 851 (1993).

15. See Caroline Keenan et al., Interviewing Allegedly Abused Children with a View to Criminal Prosecution, 1999 CRIM. L. REV. 863, 869 ("[V]ideotaping that initial interview can deliver a much fuller account of the child's experience than is likely to be achieved through examination by counsel in the courtroom.").

16. In a study of seven- to nine-year-olds, children in the "interview group" related more information in free recall, answered specific questions more often, and denied information or failed to respond to ques- 
tures the child's memories and enables the child to refresh his or her memory before making a trial appearance.

A third benefit is that videotaping reduces the stress that the legal system might otherwise exact from a child. This stress has been memorably termed the "secondary abuse" of children by the criminal justice system. ${ }^{17}$ It minimizes the number of times the child will have to retell the account and dampens the child's anxieties that reinterviewing means disbelief. ${ }^{18}$ Videotaping can even reduce or eliminate altogether the stress of direct or cross-examination. ${ }^{19}$ Because videotaping eases the child's stress, parents will be more willing to cooperate with the prosecution in supporting the need for the child to serve as a witness. ${ }^{20}$

Some investigative interviewing of the child is inevitable, since social workers and often the police are required by the laws of every state to investigate reports of child abuse, including child sexual abuse. ${ }^{21}$ All players, including, ultimately, the trier of fact, need to be able to assess the delicate interaction between the interviewer and the child, and to view the body language of both. In studies of children's interviews conducted by veteran investigators, researchers found that, even immediately after the encounter, important content was omitted in the interviewers' recall and that most of the verbatim information-the content of pivotal questions and answers-was lost. ${ }^{22}$ In sum, "interviewers, like all other adults, have limited memories." 23 As Thoreau put it, "It takes two to speak the truth-one to

tions less often than did members of the "courtroom group." Paula E. Hill \& Samuel M. Hill, Videotaping Children's Testimony: An Empirical View, 85 MICH. L. REV. 809, 815-16 (1987); Rhona Flin \& Julian Boon, The Child Witness in Court, in CHILD SEXUAL ABUSE 122-37 (Corinne Wattam et al. eds., 1989); Karen J. Saywitz and Rebecca Nathanson, Children's Testimony and Their Perceptions of Stress In and Out of the Courtroom, 17 CHILD ABUSE \& NEGLECT 613, 617 (1993) (finding a correlation between courtroom stress and impaired mnemonic performance). See also Keenan et al., supra note 15, at 868 ("This was one of several examples where patient and careful interviewing elicited a clear disclosure from the child. It would have been impossible for such an interview to have been conducted in the course of a trial.").

17. Joyce Plotnikoff \& Richard WoOlfson, Prosecuting Child Abuse: Evaluation of THE GOVERNMENT's SPEEDY PROGRESS POLICY 96 (1995).

18. The Child Abuse and Treatment Act of 1974, 42 U.S.C. $\S 5106$ (1995), created strong incentives for states to establish multidisciplinary teams for the investigation of reported cases of child abuse. By 1991, thirty-three states required joint Child Protective Services and law enforcement investigations of reported child maltreatment. One of the primary reasons for this cooperative approach was "to reduce the number of interviews with the child about the allegations." David I. Sheppard and Patricia A. Zangillo, Coordinating Investigations of Child Abuse, 54 PUB. WELFARE 21, 23-24 (1996).

19. See infra note 32 .

20. $C f$. Debra Whitcomb et Al., When the Victim Is A Child: Issues for Judges AND ProseCUTORS (1985); Mark E. Rust, The Nightmare Is Real, 14 STUD. LAW. 12 (1986).

21. See, e.g., Child Abuse and Treatment Act of 1974, 42 U.S.C. § 5106 (1995) (requiring investigations and interviews with the child victim); LA. CH. CODE art. 612 (2000) (requiring interviews of family members and of the child upon receipt of a report of abuse or neglect of a child).

22. See Michael J. Lamb et al., Accuracy of Investigators' Verbatim Notes of Their Forensic Interviews with Alleged Child Abuse Victims, 24 LAW \& HuM. BEHAV. 699 (2000); Amye R. Warren \& Cara E. Woodall, The Reliability of Hearsay Testimony: How Well Do Interviewers Recall Their Interviews with Children?, 5 PSYCHOL. PUB. POL'Y \& L. 355, 365-70 (1999).

23. Warren \& Woodall, supra note 22, at 369. See also Keenan et al., supra note 15, at 869; Maithilee K. Pathak \& William C. Thompson, From Child to Witness to Jury: Effects of Suggestion on the Transmission and Evaluation of Hearsay, 5 PSYCHOL. PUB. POL'Y \& L. 372, 383-84 (1999); Lucy Berliner \& Rozanne Lieb, Child Sexual Abuse Investigations: Testing Documentation Methods, Washington State Institute for Public Policy Doc. \# 01-01-4102, available at http://www.wsipp.wa.gov/childfamily/ChildProtection.html 
speak, and another to hear." ${ }^{24}$ Thus, a fourth benefit of videotaping is that it provides a complete, accurate record of the interchange, freeing the interviewer to relate to the child without the distraction of memory recall.

Videotaping provides for "increased transparency of the interviewing process." ${ }^{25}$ The issue is whether we know precisely what transpired at forensic interviews or whether we must only guess about it. A record of the exchange between interviewer and child is more important than a record of an adult's interrogation because a young child rarely can recall experiences without assistance from an adult, and often requires an interlocutor using prompts and cues. ${ }^{26}$ The moment an adult strides into the picture, even a helpful adult motivated only to obtain a complete and accurate account of an event, the risk of adult distortions is considerable. Although there remains some disagreement about the rationale, social scientists concur that young children are more suggestible than adults and are more likely to accept and incorporate misinformation into their memories when interacting with an authoritative adult. ${ }^{27}$ The fifth benefit of videotaping is that it permits an assessment of the likelihood of interviewer distortion.

A sixth and related benefit of videotaping is that it enables investigators to become more proficient future interviewers. The record permits review, monitoring, retraining, and enhanced self-awareness. Videotaping produces a better interview: Awareness of monitoring sharpens the interviewer's skills, and review and constructive criticism educates and makes improvement possible. ${ }^{28}$ Seventh, videotaping improves the quality of professional pretrial decisions and conserves valuable trial time, providing direct as well as indirect benefits to the criminal justice system. Both the prosecutor's staff and defense counsel can evaluate the child's

(finding videotaped recording was the most efficient and reliable method of documentation, preserving almost five times as many interviewing questions).

24. HENRY D. THOREAU, A WEEK ON THE CONCORD AND MERRIMACK RIVERS 283 (Literary Classics of the United States, Inc. 1985) (1880). (1994).

25. GRAHAM DAVIES ET AL., VIDEOTAPING CHILDREN's EvidENCE: AN EvAluATION STUdy 42

26. See Lucy S. McGough \& Amye Warren, The All-Important Investigative Interview, 45 JuV. \& FAM. СТ. J. 13, 15-32 (1994).

27. See, e.g., Stephen J. Ceci \& MAgGie Bruck, Jeopardy in the Courtroom: A SCIEnTIFIC ANALYSIS OF CHILDREN's TESTIMONY (1995); Stephen J. Ceci \& Michelle D. Leichtman, "I know that you know that I know that you broke the toy": A Brief Report of Recursive Awareness Among Three-Year-Olds, in SOCIAL AND COGNITIVE FACTORS IN EARLY DECEPTION (Stephen J. Ceci et al. eds., 1992); William C. Thompson et al., What did the Janitor Do?: Suggestive Interviewing and the Accuracy of Children's Accounts, 21 LAW \& HUM. BEHAV. 405-26 (1997). As Lord Hailsham observed in Parliamentary debate before the implementation of new interviewing procedures in Great Britain:

We have ... a good deal of cause to question the methods of interrogation of children at interviews by those who mean them well.... [S]o-called explicit [anatomically detailed doll] models have been used and suggestive questions put forward and total ignorance has been shown of the tendency of the child to give the answer he believes that the adult wishes to hear.

489 PARL. DEB., H.L. (5th ser.) (1987) 281 (speaking in opposition to the use of videotaped interviews as the child's evidence-in-chief; the legislation ultimately was enacted by Parliament). See also supra note 9 (discussing videotaping procedures in Great Britain).

28. See Myers, supra note 12, at 375 n.34 (citing Mike McConville, Videotaping Interrogations: Police Behavior On and Off Camera, 1992 CRIM. L. REV. 532.) For a discussion of the use of videotapes in training and the improvement of interviewing skills, see Helen L. Westcott et al., Children, Hearsay, and the Courts: A Perspective from the United Kingdom, 5 PSYCHOL. PUB. POL'Y \& L. 282 (1999). 
accusation before deciding whether to go to trial. ${ }^{29}$ Videotaping also conserves valuable professional time before trial. Rather than scheduling and conducting independent interviews of the child, counsel, agency staff, and consultants can view the preserved account. Finally, videotaping saves the child's account for potential use at trial if the child becomes unavailable for complete testimony. A videotaped record of an out-of-court declaration, although hearsay, can meet the requirements of White $v$. Illinois ${ }^{30}$ and thus be used as evidence at trial. ${ }^{31}$ At least ten states have expressly authorized the videotaping of a child's statement for later use at trial. ${ }^{32}$

\section{B. The Costs of (Worries About) Videotaping Forensic Interviews}

There are six commonly cited disadvantages to videotaping, beginning with the financial costs. Undeniably, there are start-up costs for buying video equipment and supplies, as well as continuing expenses for equipment repair and the salary costs of equipment operation. Many communities, however, already have access to Child Advocacy Centers that provide videotaping facilities for child victim in-

29. The often-touted assumption that a videotape "increases guilty pleas" has yet to be proved. DEBRA WhitCOMB ET AL., WHEN THE Victim IS A CHILD: ISSUES FOR JUDGES AND PROSECUTORS 60 (1st ed. 1965). The Home Office-commissioned study found a "trend," but not one of statistical significance. DAVIES ET AL., supra note 25, at 35. Furthermore, it would not necessarily be a just result if videotaping only produced more guilty pleas (above the general average) when decisions not to prosecute did not also rise, unless we assume that every allegation of sexual abuse is in fact true.

30. 502 U.S. 346 (1992).

31. According to White, the Supreme Court's latest exegesis of the constitutional dimensions of hearsay rules in child abuse prosecutions, the child's hearsay complaint is admissible if the state produces the child as a witness or alternatively shows that the child is "unavailable" and that the hearsay exhibits sufficient indicia of reliability. 502 U.S. at 357. Lower courts have interpreted constitutional unavailability in a variety of settings. See United States v. Grooms, 978 F.2d 425, 428 (8th Cir. 1992) (holding that lack of memory does not render cross-examination constitutionally deficient); Commonwealth v. Willis, 716 S.W.2d 224, 230 (Ky. 1986) (finding the child witness too frightened or inarticulate to testify); State v. R.C., Jr., 494 So. 2d 1350, 1356 (La. Ct. App. 1986) (interpreting refusal to testify); Commonwealth v. Tufts, 542 N.E.2d 586, 588-89 (Mass. 1989) (finding severe emotional distress); State v. Slider, 688 P.2d 538, 541 (Wash. Ct. App. 1984) (interpreting child's loss of memory).

32. See Lucy S. McGough, For the Record: Videotaping Investigative Interviews, 1 PsYCHOL. PUB. POL'Y \& L. 1 (1995). Two early pre-White state court decisions declared such statutes unconstitutional in violation of the Sixth Amendment Confrontation right. People v. Bastien, 541 N.E.2d 670 (Ill. 1989); Long v. State, 742 S.W.2d 302, 318 (Tex. Crim. App. 1987) (en banc). Those decisions probably spooked other states from enacting similar evidentiary rules that would permit the trial use of videotapes. In the subsequent decade, however, both decisions were overruled. Long was overruled and modified by Briggs $v$. State, 789 S.W.2d 918, 924 (Tex. Crim. App. 1990) (en banc). More recently, the Supreme Court of Illinois has reversed field from its Bastien decision and endorsed the use of videotaped statements, at least when the child is produced for direct and cross-examination at trial. State v. Bowen, 699 N.E.2d 577 (Ill. 1998). In a rather remarkable about-face, the Court danced very close to a finding that a videotaped version of a child's early report was more reliable than any trial version the child might give. $I d$. at 584-85.

In contrast, the Arizona Court of Appeals recently invalidated its children's interviewing videotaping statute on grounds that the legislature, by attempting to alter the rules of evidence, had infringed upon the exclusive prerogative of the state Supreme Court. State v. Taylor, 2 P.3d 674, 678 (Ariz. Ct. App. 1999). The court notes, however, that the state failed to produce any evidence to substantiate a claim that the memorial capabilities of children are any different from those of adults or that special hearsay rules can be justified. Such evidence abounds. See generally MCGOUGH, supra note 7. 
terviews as standard operating procedure, ${ }^{33}$ and many police departments now routinely videotape traffic stop encounters on the open road and interrogations of criminal suspects charged with more serious offenses. ${ }^{34}$ Undeniably, some locales have not yet provided this technology to their police or social services, and so would have to make a modest investment of public funds.

An argument often misdirected at videotaping is that social workers and police cannot be trained to conduct an effective child victim interview. ${ }^{35}$ The less arrogant variant is that there are insufficient funds to train competent forensic interviewers. $^{36}$ The frightening import of such assertions is this implicit tolerance of criminal prosecutions that, a fortiori, must rely upon highly suspect accusations from children. These attacks do not concern the merits of videotaping, except insofar as videotaping forces an awareness of ineptitude. As John Spencer has written, just because there may be "bad" interviews does not mean that we have to do without the "good" ones." The real question is whether videotaping or doing without will produce the better interview, both in the present interview and in any future interviews that a professional may conduct. ${ }^{38}$

Some have voiced a third concern that the child's privacy will be compromised if a videotape is made; a variant is that the tapes will be used and might even fall into the hands of child pornographers. ${ }^{39}$ There is no apparent reason why this evidence cannot be secured, as is other forensic physical evidence, which is usually held under lock and key before trial. A protocol is needed that would acknowl-

33. There apparently are no national or regional estimates of the costs of outfitting an interviewing room with videorecording equipment, since costs and projected needs vary widely from community to community. E-mail correspondence with Joelyn Doland, Director, Child Advocacy Center, Lake Charles, La. (Jan. 21, 2001); telephone conversation with Benjamin Murray, Chapter Coordinator, National Children's Alliance, Washington, D.C. (Feb. 6, 2001).

34. As early as 1975, the American Law Institute proposed a requirement that sound recordings be made of the interrogation process. See Model CodE OF PRE-ARRAIGNMENT Procedure $§ 130.4(3)$ (1975). The Supreme Court of Alaska has construed its state constitution's due process guarantee to require electronic recording of all custodial interrogations. See Stephan v. State, 711 P.2d 1156, 1162 (Alaska 1985). In exercise of its supervisory power to ensure the "fair administration of justice," the Minnesota Supreme Court has adopted a recording requirement. State v. Scales, 518 N.W.2d 587, 592 (Minn. 1994). Courts in other states like Indiana and Massachusetts have strongly recommended the practice. See Stoker v. State, 692 N.E.2d 1386, 1390 (Ind. Ct. App. 1998); Commonwealth v. Diaz, 661 N.E.2d 1326, 1329 (Mass. 1996). See also Richard A. Leo, The Impact of Miranda Revisited, 86 J. CRIM. L. \& CRIMINOLOGY 621, 681-92 (1996).

35. See Jeffery Wilson, A Perspective on the Canadian Position, in CHILDREN's EVIDENCE IN LEGAL ProceEdings: An INTERNATIONAL PERSPECTIVE 147, 155 (J.R. Spencer et al. eds., 1989).

36. Jan Aldridge, The Further Training of Professionals Dealing with Child Witnesses, in CHILDREN AS WITNESSES 231-33 (Helen Dent \& Rhonda Flin eds., 1992); Warren \& Woodall, supra note 22.

37. J.R. Spencer, Children's Evidence in Legal Proceedings in England, in CHILDREN's EVIDENCE IN LEGAL PROCEEDINGS, supra note 35, at 113, 122.

38. See id.

39. See DAVIES ET AL., supra note 25, at 45 (reporting that, initially, some British social workers were similarly concerned); Kee MacFarlane, Diagnostic Evaluations and the Use of Videotapes in Child Sexual Abuse Cases, 40 U. MIAMI L. REV. 135, 151 (1985) (expressing concern that videotapes might be available to the press). 
edge the privacy concern and require investigators and interviewers to safeguard the videotapes in accordance with established procedures. ${ }^{40}$

Still other critics note quite accurately that a young child's narrative of a remembered event is typically abbreviated and often not straightforward. ${ }^{41}$ If the child later remembers details that were not given at an earlier interview or interviews, later doubts some details that were given earlier, or otherwise changes his or her account, some fear that the presence of the videotaped version will cause everyone to doubt the core truth of the child's accusation. ${ }^{42}$ Therapists point out that years can elapse before some patients are able to confront the reality of abuse. $^{43}$ If, for example, in the first session a child victim says little or claims nothing occurred, but four months later accuses an assailant, will the child improperly be viewed as fantasizing or lying? ${ }^{44}$

Future revision is a universal problem, but one fairly easily solved. Any videotaping protocol must provide for the taping of all forensic interviews, including any later ones that revise an initial account, and should permit the child to offer an explanation for any reassessment of the remembered events. ${ }^{45}$ Memory revisions may cause naïve prosecution staff to be skeptical, and certainly any modifications will be highlighted by defense counsel to undermine the child's credibility; there is no reason, however, that revision per se should invalidate the child's accusation.

40. Courts are quite accustomed to handling evidence that is subject to policies of confidentiality, such as social services records, adoption records, and grand jury proceedings. There is no reason why a protective order mechanism could not be employed to safeguard the videotape and its legitimate use. The British have developed highly efficient and apparently satisfactory safeguards for videotapes of child victims' interviews. For an assessment, see DAVIES ET AL., supra note 25, at 10. The inadvertent loss of videotapes, illustrated by the negligent practices of the police in Morgan v. Gertz, 166 F.3d 1307 (10th Cir. 1999), would also be eliminated with adoption of safekeeping protocols. See infra text accompanying note 158.

41. Everyone who follows the interviewing literature develops his or her own favorite anecdote about the frustrations of the task. My own current favorite has been passed along by British investigators who lament the difficulty of avoiding leading questions and note that broad questions often miss the mark. One investigator recalled interviewing a young boy who had allegedly been abused by his babysitter:

I said to him: "Have you got any concerns about anyone?" and he said "Yes." And so I said,

"Well, who's that?" and he said "Eric Cantona." He said he was worried that Eric Cantona would leave Manchester United. The whole interview was about Eric Cantona. That was his worry.

Keenan et al., supra note 15, at 871. Eric Cantona is the Michael Jordan of British soccer.

42. See WHITCOMB ET AL., supra note 29, at 138.

43. See the claims of therapists collected in ElizABETH Loftus \& KATHERINE Ketcham, ThE MYTH OF REPRESSED MEMORY (1994). Miss America Marilyn Van Derbur recalled "repressed" memories of childhood incest over twenty years later when she was an adult. Marilyn V. Atler \& Vickie Bare, The Darkest Secret, PEOPLE, June 10, 1991, at 89; see also Elizabeth F. Loftus \& Leah Kaufman, Why Do Traumatic Experiences Sometimes Produce Good Memory (Flashbulbs) and Sometimes No Memory (Repression)?, in AFFECT AND ACCURACY IN RECALL: STUDIES OF "FlASHBULB” MEMORIES 212 (Eugene Winograd \& Ulrie Neisser eds., 1992).

44. See Wilson, supra note 35, at 155.

45. In one proposed model statute, a child may disclaim an earlier account in whole or in part and provide a new version. Videotapes of all versions of the child's experience would be made and considered collectively as evidence. See MCGough, supra note 6, at 271-74 (citing Proposed Statute 3, RecollectionRecorded Videotapes of Children's Statements for Use in Criminal Trials). In addition to the use of videotaped interview, the current British statute permits testimony at trial by the child about any new matter not discussed in previous interviews and, with the court's permission "in the interests of justice," testimony that retraces and modifies a previous account. See Youth Justice \& Criminal Evidence Act, c. 23 § 27(5)-(7) (1999) (Eng.). 
Expert testimony would confirm that research demonstrates that changes in peripheral details, delayed recall, and recanting often occur in children's testimony. ${ }^{46}$ Few, if any, experiences are seared in perfect clarity in adult memory, much less a child's more fragile one. ${ }^{47}$ Expert witnesses and jury instructions are the law's usual responses to information that is beyond the understanding of the average juror $^{48}$ and may be adequate to curb ignorance about children's veracity or reliability. ${ }^{49}$ The possibility of revision of the accusation does not undercut the value of a record of earlier interviews, unless we want to pretend that earlier versions were never voiced.

Barbara Smith's study of prosecutors found that they rated those innovations involving videotaping as the most infrequently used..$^{50}$ Prosecutors constitute a powerful force, and their reluctance or outright opposition may help to explain why videotapes are so infrequently made and why statutory reform has slowed to a standstill. Several studies have found that prosecutors are conservative and unlikely to embrace evidentiary innovations unless they are easy, quick, and inexpensive to implement. ${ }^{51}$ Gail Goodman's most recent research found that "lack of money" and "hurts case" were tied as reasons offered by nearly half of the prosecutors surveyed for not making videotapes of children's statements. ${ }^{52}$ Videotaping is believed to hurt the prosecution by diminishing the child's credibility in two ways: The videotaped account may be a less convincing presentation than live tes-

46. Denial, revision, and recanting an earlier disclosure are discussed as dynamics of sexual abuse by many social scientists. See, e.g., DAVID P.H. JONES \& MARY MCQUISTON, INTERVIEWING THE SEXUALLY ABUSED CHILD 3-7 (2d ed. 1986).

47. M. McCloskey et al., Is There a Special Flashbulb-Memory Mechanism?, 117 J. EXPER. PSYCHOL.: GEN. 171-81 (1988); Amye Richelle Warren \& Jeffrey N. Swartwood, Developmental Issues in Flashbulb Memory Research: Children Recall the Challenger Event, in AFFECT AND ACCURACY, supra note 43, at 95. Both studies document substantial forgetting and unreliability of memory of the Challenger disaster, despite the fact that the subjects firmly believed that the event had been indelibly recorded and was an infallible memory.

48. See MCCORMICK ON EVIDENCE $\S \S 13,328$ (J.W. Strong ed., 5th ed. 1999). For a discussion of the use of expert witnesses in child abuse cases, see Lucy S. McGough, A Legal Commentary: The Impact of Daubert on 21st Century Child Sexual Abuse Prosecutions, in EXPERT WITNESSES IN CHILD ABUSE CASES 265 (Stephen J. Ceci \& Helene Hembrooke eds., 1998), and John E.B. Myers et al., Expert Testimony in Child Sexual Abuse Litigation, 68 NEB. L. REV. 1 (1989).

49. This is an issue that needs greater study, however. Kovera and Borgida report that there has been only one investigation of the impact of expert testimony about children's mnemonic capabilities upon jurors. See Margaret B. Kovera \& Eugene Borgida, Expert Scientific Testimony on Child Witnesses in the Age of Daubert, in EXPERT WITNESSES IN CHILD ABUSE CASES, supra note 48, at 190-91. Crowley and colleagues found that expert testimony affirming children's mnemonic strengths appeared to influence jurors who found a child witness more credible and less susceptible to suggestion than did jurors who did not hear the expert. See Michael J. Crowley et al., The Juridical Impact of Psychological Expert Testimony in a Simulated Child Sexual Abuse Trial, 18 LAW \& HUM. BEHAV. 89, 100 (1994).

50. Barbara E. SMith \& Sharon G. Elstein, The Prosecution of Child SeXual and Physical ABuse CASES (Final Report to the National Center on Child Abuse and Neglect), The American Bar Foundation, Fund for Justice and Education on Behalf of the ABA Center on Children \& the Law 54-55 (1993).

51. See Ellen Gray, Unequal Justice: The Prosecution of Child SeXual Abuse (1993); Gail S. Goodman et al., Innovations for Child Witnesses: A National Survey, 5 PsYCHOL. PUB. POL'Y \& L. 255 (1999).

52. See Goodman et al., supra note 51, at 271. 
timony by the child, and a videotaped record can give ammunition to defense counsel to point out the inevitable inconsistencies of the child's account.

The fifth concern, often voiced by prosecutors, is that a videotaped version degrades the child's credibility, that is, that it is a less powerful form of testimony. As one investigator has more vividly put it, the prosecutors would "rather have the child squirming in the witness box than use a sterile video." 53 Davies study of prosecutions in England found no such effect either upon assessments of videotaped children's credibility or upon rates of acquittal. ${ }^{54}$ The simulated study by American researchers reached similar findings. ${ }^{55}$

The more commonly-expressed prosecutorial fear is that a videotaped record fuels the effectiveness of cross-examination, and that overreaching, overzealous defense counsel will misuse any discrepancies in the child's account or flaws in the interviewer's elicitation of the narrative to undermine or even destroy the child's credibility. ${ }^{56}$ Furthermore, many prosecutors believe that juries and judges cannot tell the difference between minor and major inconsistencies or between core and peripheral details, and that triers of fact cannot distinguish between the effective use of cross-examination and its misuse. Indeed, many high-profile sexual abuse prosecutions foundered in the 1980s, perhaps principally due to expert testimony about the suggestive interviewing techniques used by the investigators in videotaped interactions. As Stephen Ceci has noted, the McMartin jury hung on thirteen counts where there were no videotaped interviews of the children; they acquitted the defendants where there were videotapes of highly suggestive interviewing. ${ }^{57}$ The Kelly Michaels conviction was reversed and further testimony from the alleged child victims was barred because the New Jersey appellate courts found that the videotaped interviews were so permeated with improper suggestion that accuracy could no longer be unraveled from inaccuracy. ${ }^{58}$ Ironically, these day-care cases, which may well lie at the extreme edge of prosecutorial frenzy and interviewer overreaching, have been taken as the exemplars of forensic interviewing and thus have created resistance to videotaping. We do not know with any certainty how bad or good forensic interviewing practice currently is, because we lack a record of practice norms.

53. The Child, The Court And The Video: A Study of The IMPlementation of the MEMORANDUM OF GOOD PRACTICE ON VIDEO INTERVIEWING OF CHILD WitNESSES 24 (Department of Health, Social Services Inspectorate, 1994).

54. DAVIES ET AL., supra note 25, at 35.

55. See David F. Ross et al., The Impact of Protective Shields and Videotape Testimony on Conviction Rates in a Simulated Trial of Child Sexual Abuse, 18 LAW \& HUM. BEHAV. 553, 564-66 (1994).

56. See DAVIES ET AL., supra note 25, at 44; WhITCOMB ET AL., supra note 29, at 138; Flin \& Boon, supra note 16, at 130-31; Lamb et al., supra note 10, at 444; MacFarlane, supra note 39.

57. Professor Ceci has made this point in several speeches, for example, at the Society for Research in Child Development Conference (Sept. 15, 1993), but apparently has never noted it in a manuscript. E-mail correspondence with Stephen J. Ceci (Jan. 30, 2001).

58. See State v. Michaels, 642 A.2d 1372, 1379-80 (N.J. 1994). 
Prosecutorial resistance to videotaping is surely not surprising and, indeed, it is reminiscent of resistance to discovery a half-century $\mathrm{ago}^{59}$ and to the right of an accused to summon defense witnesses centuries earlier. ${ }^{60}$ Then, as now, the arguments conjure up the specter of abusive defense practices, whine about the unfairness of the unilateral protections of the accused in the American constitutional system, and argue that the success of videotaping in other countries is idiosyncratic and not transferable here. ${ }^{61}$

The United States has not followed the path of other countries in either standardizing interviewing protocols or universally enacting statutes authorizing and regulating child witness videotaping. We have so far lacked the political will to implement reforms, even though public attitudes about the value of videotaped records have clearly changed, thanks to the Rodney King beating, the Central Park melee after the National Puerto Rican Day Parade, and instant replays in sports. If there is no foreseeable legislative reform, then alternatives should be explored for establishing more videotaping facilities. As discussed above, the irreplaceable benefits of making a videotaped record of forensic interviews with child victims suggest that the prosecutor might have a constitutional duty to preserve the child's account. In the tort action for spoliation of evidence, ${ }^{62}$ the duty to preserve certain evidence is derived from statute, the parties' contract, or through a special fiduciary relationship. ${ }^{63}$ In criminal prosecutions, the Due Process Clause emerges as a fourth source.

59. Compare William J. Brennan, The Criminal Prosecution: Sporting Event or Quest for Truth?, 1963 Wash. U. L.Q. 279, with William J. Brennan, The Criminal Prosecution: Sporting Event or Quest for Truth?: A Progress Report, 68 WASH. U. L.Q. 1 (1990) [hereinafter Brennan, A Progress Report].

60. That a defendant might abuse discovery "is no reason for committing the injustice of refusing the honest accused a fair means of clearing himself. That argument is outworn; it was the basis (and with equal logic) for the one-time refusal of the criminal law ... to allow the accused to produce any witnesses at all." Brennan, A Progress Report, supra note 59, at 13 (citing 6 J. WIGMORE, EVIDENCE $§ 1863$, at 488 (3d ed. 1940)).

61. See State v. Tune, 98 A.2d 881 (N.J. 1953) (refusing to grant to the accused the right to have a copy of his own confession). Broader rights of discovery, including the right to one's own confession, are now recognized by the Federal Rules of Criminal Procedure, specifically Rule 16. FED. R. CRIM. P. 16. In England, prosecutors are subject to provide full disclosure and are ethically bound not "to obtain a conviction by a means at his command. He should not regard himself as appearing for a party." R. 11.1, Responsibilities of Prosecuting Counsel, Standards Applicable to Criminal Cases, in CODE OF CONDUCT OF THE BAR OF ENGland AND Wales (1990). See also Anthony Heaton-Armstrong \& David Wolchover, On the Record-Should Prosecution Witnesses Have Their Statements Recorded in the Same Way as Those Made by Suspects, 90 LAW SOC'Y GAZETTE 25 (1993).

62. The elements of intentional spoliation of evidence are: (1) likely litigation involving the plaintiff; (2) defendant's knowledge of that fact; (3) intentional acts that destroy, discard, alter or otherwise affect the evidence which are designed to disrupt the plaintiff's cause of action; (4) disruption of the plaintiff's case actually occurs; and (5) the plaintiff's damages are caused by the defendant's acts. See Foster v. Lawrence Mem. Hosp, 809 F. Supp. 831 (D. Kan. 1992); Solano v. Delaney, 264 Cal. Rptr. 721 (Cal. Ct. App. 1989), cited in Maria A. Losavio, Synthesis of Louisiana Law on Spoliation of Evidence-Compared to the Rest of the Country, Did We Handle It Correctly?, 58 LA. L. REV. 837, 844 (1998).

63. Losavio, supra note 62, at 850-53. 
III

\section{“ACCESS TO EVIDENCE” ClAims}

\section{A. The Supreme Court's Analysis of Federal Constitutional Claims}

In only a handful of cases has the Supreme Court had occasion to consider the contours of what it has referred to as its "constitutionally guaranteed access to evidence" jurisprudence. ${ }^{64}$ The rationale for finding due process protection has been articulated best by Justice Marshall:

One of the most basic elements of fairness in a criminal trial is that available evidence tending to show innocence, as well as that tending to show guilt, be fully aired before the jury; more particularly, it is that the State in its zeal to convict a defendant not suppress evidence that might exonerate him.... No interest of the State is served, and no duty of the prosecutor advanced, by the suppression of evidence favorable to the defendant. On the contrary, the prosecutor fulfills his most basic responsibility when he fully airs all the relevant evidence at his command. ${ }^{65}$

Despite this glowing rhetoric, however, the Rehnquist Court's opinions have acknowledged only grudgingly that fundamental fairness has any impact upon the development of evidence by investigators and prosecutors. There are two chains of decisions: scenarios involving the state's failure to disclose to the accused information within its possession, which it has either passively gathered or actively produced; and scenarios involving the state's failure to collect all relevant evidence or thereafter to preserve it. Both types of cases display state action or inaction, ordinarily during the investigatory stages, that may compromise the ability of the accused to defend against the charges later.

1. The Duty to Disclose Evidence. The most famous "duty to disclose" decision is Brady v. Maryland ${ }^{66}$ in which the Court held that due process is violated when, despite a defense request, the government suppresses exculpatory evidence, that is, "evidence favorable to the accused ... where the evidence is material either to guilt or to punishment." ${ }^{67}$ Similarly, in Giglio v. United States ${ }^{68}$ the Court found that due process was offended by the prosecutor's failure to disclose to the defendant that a prosecution witness was testifying under immunity. Thus, Giglio extended the circle of constitutional claims to include information that would be helpful in impeaching a government witness.

In United States v. Agurs, ${ }^{69}$ and later United States v. Bagley, ${ }^{70}$ the Court made it clear that a defendant's failure to request exonerative evidence did not leave the

64. United States v. Valenzuela-Bernal, 458 U.S. 858, 867 (1982).

65. United States v. Agurs, 427 U.S. 97, 116 (1976) (Marshall, J., dissenting) (citations omitted).

66. 373 U.S. 83 (1963). Although Brady is the most famous duty-to-disclose case, the Court had granted relief earlier, when the state withheld significant information. In Napue v. Illinois, 360 U.S. 264 (1959), and Mooney v. Holohan, 294 U.S. 103 (1935), the Court found a denial of due process when the prosecutor failed to inform the defense (and the trial court) that one of the prosecution's witnesses had perjured himself in his trial testimony.

67. Brady, 373 U.S. at 87.

68. 405 U.S. 150 (1972).

69. 427 U.S. 97 (1976). 
government free from an affirmative obligation to turn over highly material evidence. Favorable evidence is material if "there is a reasonable probability that, had the evidence been disclosed to the defense, the result of the proceeding would have been different." Justice Souter has struggled most to clarify the materiality test. Most recently he has suggested that the test is properly reframed as a "significant possibility" that withheld evidence would alter the judgment. ${ }^{72}$ The good or bad faith of the government is not an articulated element of the materiality test because bad faith-sharp, "gladiatorial" practice-is presumed from the fact of the suppression of clearly favorable evidence. ${ }^{73}$ Its apparent exculpatory value should prompt any reasonable prosecutor to disclose it.

In these cases, including the one involving the Tennessee daycare investigation interview videotape, the defense has somehow later learned of the existence of the suppressed evidence. When the evidence is still in existence, its exculpatory value can be evaluated by the court for whether a reasonable prosecutor should have disclosed it.

2. The Duty to Collect and Preserve Evidence for Disclosure. This branch of constitutional doctrine constitutes a more intrusive and speculative review of prosecutorial activity because it calls into question whether the police fully and competently investigated a case and gathered evidence. The court is asked to assess the exonerative value of evidence that does not now exist because it was either never collected or has since been destroyed, discarded, or lost. Further-

70. 473 U.S. 667 (1985).

71. Id. at 682 .

72. Justice Souter wrote:

The Court rightly cautions that the [reasonable probability] standard intended by these words does not require defendants to show that a different outcome would have been more likely than not with the suppressed evidence, let alone that without the materials withheld the evidence would have been insufficient to support the result reached. Instead, the Court restates the question (as I have done elsewhere) as whether "the favorable evidence could reasonably be taken to put the whole case in such a different light as to undermine confidence" in the outcome.

Despite our repeated explanation of the shorthand formulation in these words, the continued use of the term "probability" raises an unjustifiable risk of misleading courts into treating it as akin to the more demanding standard, "more likely than not." While any short phrases for what the cases are getting at will be "inevitably imprecise," I think "significant possibility" would do better at capturing the degree to which the undisclosed evidence would place the actual result in question, sufficient to warrant overturning a conviction or sentence.

Strickler v. Greene, 527 U.S. 263, 297-98 (Souter, J. concurring and dissenting) (citations omitted).

Twenty years before, the eminent Chief Judge Elbert Tuttle of the old Fifth Circuit Court of Appeals provided a clearer encapsulation of the review standard in Freeman v. Georgia, 599 F.2d 65, 69 (5th Cir. 1979), although the defendant's burden of proof is arguably less onerous: "[D]ue process has been violated and habeas must be granted if, in the context of the entire trial, the missing witness's testimony was such as might have created a reasonable doubt which would not otherwise have existed."

73. Again, in the words of Justice Souter:

Unless, indeed, the adversary system of prosecution is to descend to a gladiatorial level unmitigated by any prosecutorial obligation for the sake of truth, the government simply cannot avoid responsibility for knowing when the suppression of evidence has come to portend such an effect on a trial's outcome as to destroy confidence in its result.

Kyles v. Whitley, 514 U.S. 419, 439 (1995). 
more, the court must evaluate whether the police acted reasonably in their investigation of the case and collection of evidence for trial. The apparent test is not what Columbo would have done but what a reasonably well-trained police officer would do. ${ }^{74}$ Is there a constitutional duty for police to find the murder weapon, ${ }^{75}$ to preserve marijuana for testing ${ }^{76}$ to take possession of the surveillance videotape in a bank robbery case,$^{77}$ to order swabs of bodily fluids for identifying DNA in rape cases, ${ }^{78}$ to identify eyewitnesses, or to record their accounts while fresh in their memory ${ }^{79}$ Ordinarily, such investigative activities occur because the police want enough evidence to secure a successful prosecution of the perpetrator. But must the police exhaust or even pursue investigative leads? Do police still play a neutral investigatory role so that all investigative leads are exhausted, even those that might cast doubt on the culpability of a prime suspect? Will an accused later be heard to complain that some failure of the police to gather a particular piece of evidence violated his or her right to fundamental fairness at trial?

Clearly not every failure to preserve evidence is of constitutional magnitude. In Killian v. United States, ${ }^{80}$ the Supreme Court held that investigators' practice of discarding notes used to compile reports that were then received into evidence did not violate due process. ${ }^{81}$ United States $v$. Valenzuela-Bernal ${ }^{82}$ presented yet another type of failure to preserve trial evidence: the deportation of potential trial witnesses. The Court held that this action did not deny the defendant a fair trial when the prosecutor's action was neither malicious nor negligent but instead was pursuant to routine policy. ${ }^{83}$ In California $v$. Trombetta, ${ }^{84}$ investigators took a breath sample, analyzed it for blood alcohol content, and then discarded it. The Court, again, found no due process violation. ${ }^{85}$ In Arizona v. Youngblood ${ }^{86}$ the

74. The reasonably well-trained police officer standard was used by the Court in assessing the good faith of an officer's claimed reliance upon the legitimacy of a warrant. See United States v. Leon, 468 U.S. 897, 922 n.23 (1984).

75. See State v. Woods, 1999 WL 1136764 at $* 5$ (Wash. Ct. App. 1999) (unpublished opinion) (holding that the failure to preserve potentially useful evidence does not violate due process absent bad faith).

76. See United States v. Belcher, 762 F. Supp. 666, 672-73 (W.D. Va. 1991) (holding that such a duty to preserve existed).

77. See United States v. McClure, 1990 U.S. App. LEXIS 20371 at *15-18 (4th Cir. 1990) (holding that there was no duty when the evidence indicated that the loss of evidence resulted from the officer's negligent act); People v. Walker, 628 N.E.2d 971 (Ill. App. Ct. 1993) (holding that destruction of certain items of clothing constituted a denial of due process, when they were material to the robbery defendant's defense of misidentification).

78. See Mitchell v. Goldsmith, 878 F.2d 319, 322 (9th Cir. 1989) (holding that the state's failure to preserve a semen sample or perform enzyme analysis on the sample in rape case was not a violation of defendant's due process rights).

79. See Commonwealth v. Small, 741 A.2d 666 (Pa. 1999) (holding no duty to record preliminary conversations with potential witnesses).

80. 368 U.S. 231 (1961).

81. Id. at 242 .

82. 458 U.S. 858 (1982).

83. Id. at 872 .

84. 467 U.S. 479 (1984).

85. Id. at 488 .

86. 488 U.S. 51 (1988). 
police failed to perform certain chemical tests on samples gathered in a sexual assault kit and failed to refrigerate the victim's clothing so that other tests might be conducted. The Court again found no due process violation. ${ }^{87}$ Collectively, these cases display a very bleak and inhospitable constitutional landscape for pressing any videotaping claim based on a duty to preserve evidence. With a more detailed analysis of the Court's concerns, however, such a claim appears more viable.

In Youngblood, the Court also held that due process imposes no affirmative duty upon the state to use the best available technology, so there is no prosecutorial duty to conduct newer, more definitive tests on evidence samples. This debate has taken on increasing significance over the past sixteen years due to the availability of DNA testing that can completely exonerate a wrongfully accused or convicted citizen. ${ }^{88}$ With little discussion, the Court dismissed the cutting-edge technology claim, noting that it "strongly" disagreed with any notion that due process requires the police to use "a particular investigatory tool." 89 In Idaho $v$. Wright ${ }^{90}$ the Court applied this principle to the videotaping of a child victim's statement.

In the Wright prosecution, a pediatrician questioned a two and one-half-yearold girl in the course of a medical evaluation. The doctor failed to make any videotaped or audiotaped record of the interview and instead relied upon his memory refreshed by notes about the interview he had dictated to the file. The trial court permitted the child's accusation to be presented by the doctor under the residual exception to the hearsay rule, but the Idaho Supreme Court reversed the evidentiary ruling and the conviction, observing that "[t]he circumstances surrounding this interview demonstrate dangers of unreliability which, because the interview was not [audio- or video-] recorded, can never be fully assessed." ${ }^{91}$ The United States Supreme Court agreed that, under a totality-of-the-circumstances test, the state had not carried its burden of proving that the child's hearsay was particularly trustworthy, singling out for concern the "suggestive manner" in which the interview was conducted as casting the greatest doubt on the reliability of the child's accusation. The following is the critical portion of the reported direct examination:

A. [After a rapport-building exchange], I then proceeded to just gently start asking questions about, "Well, how are things at home," you know, those sorts. Gently moving into the domestic situation and then moved into four questions in particular, as I reflected in my records, "Do you play with daddy [the stepfather]? Does daddy play with you? Does daddy touch you with his pee-pee? Do you touch his pee-pee?" And again we then established what was meant by pee-pee, it was a generic term for genital area.

Q. Before you get into that, what was, as best you recollect, what was her response to the question, "Do you play with daddy?"

87. Id. at 58 .

88. See generally JiM DWYER ET AL., ACTUAL INNOCENCE (2000).

89. See Youngblood, 488 U.S. at 58-59.

90. 497 U.S. 805 (1990).

91. Id. at 813 . 
A. Yes, we play-I remember her making a comment about yes we play a lot and expanding on that and talking about spending time with daddy. ... When I asked her "Does daddy touch you with his pee-pee, she did admit to that. When I asked, "Do you touch his pee-pee," she did not have any response.

The doctor stated that, although he had dictated notes to summarize the conversation, they were not detailed and did not record any changes in the child's affect or attitude. The mother and stepfather were convicted of lewd conduct and sentenced to twenty years' imprisonment. ${ }^{93}$

Although the Court found the doctor's hearsay account unreliable, it indicated in dictum that recording a child's interview was not a constitutional prerequisite for the admissibility of the child's account:

Out-of-court statements made by children regarding sexual abuse arise in a wide variety of circumstances, and we do not believe the Constitution imposes a fixed set of procedural prerequisites to the admission of such statements at trial. The procedural requirements identified by the court below, to the extent regarded as conditions precedent to the admission of child hearsay statements in child sexual abuse cases, may in many instances be inappropriate or unnecessary to a determination whether a given statement is sufficiently trustworthy for Confrontation Clause proposes. Although the procedural guidelines propounded by the court below may well enhance the reliability of out-of-court statements of children regarding sexual abuse, we decline to read into the Confrontation Clause a preconceived and artificial litmus test for the procedural propriety of professional interviews in which children make hearsay statements against a defendant. $^{94}$

At broad brush, this dictum certainly makes sense. As the Court notes, if recording were the sine qua non of admissibility of all children's hearsay, many types of very reliable information might be excluded. On the other hand, were it not for the candor, and perhaps the naïveté, of this doctor, the Court could not have determined that the reliability of the hearsay had been compromised by his suggestiveness.

In Wright, it is not clear that the child was sent to a pediatrician for a forensic interview, that is, that the evaluation was to be made for the sole or primary purpose of creating a record of the child's account of the abuse for use at trial. Certainly this doctor was a member of the prosecutorial team who was engaged to make a physical evaluation of the child that would be presented through his testimony at trial. Indeed, the doctor is described as having had extensive experience in child sexual abuse cases. In Wright, however, the Court arguably was not faced with the government's failure to record a forensic interview of a child. Thus, short of expressly disavowing its dictum in Wright that there is no constitutional duty to record an out-of-court statement made by a child, the Court may be able to distinguish that encounter from the forensic interview typically conducted by a police or social services investigator. When accusations by a child are purposefully sought by the government, a telling argument can be made that due process commands that the encounter be preserved and disclosed to anyone accused by the child and prosecuted.

92. Id. at $810-11$.

93. Id. at 812 .

94. Id. at $818-19$ (citations omitted). 


\section{B. The Murkiness of the Preservation Duty: The Interrelationship Between Trombetta and Youngblood}

In the California v. Trombetta decision, ${ }^{95}$ the United States Supreme Court considered Trombetta's claim that state investigators had a duty to preserve a breath sample they had tested in his drunk-driving case. Trombetta urged that, when the state creates test results evidence and seeks to use it at trial, there is a duty to make the testing sample available to an accused for independent analysis. Because the government failed to preserve the sample for defense testing, he argued, due process barred the use of the state's test results. In a unanimous opinion, the Court rejected the claim, holding on these facts that there was no such constitutional duty; however, Justice Marshall's opinion for the Court hinted that other similar claims might fare better. The factoring approach used by the Court in Trombetta included consideration of three elements: (1) whether the prosecution's failure was a calculated effort to circumvent Brady v. Maryland ${ }^{96}$ or instead was an action taken in good faith and in accord with normal practice; (2) whether the defense value of the evidence was apparent before it was destroyed, that is, whether it "might be expected to play a role in the suspect's defense"; and (3) whether the accused could obtain comparable evidence by other reasonably avail-

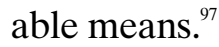

Unlike Trombetta, which may be thought of as a failure to preserve leftovers from state testing, Arizona v. Youngblood ${ }^{98}$ involved the state's failure to preserve evidence for any analysis - the failure to preserve semen samples and to refrigerate the victim's clothing so that the semen stains could be tested to identify features of the assailant. Youngblood is especially interesting since the victim was a ten-year-old boy and what seemed to be evidence critical to the identification of his sexual assailant was lost.9. Although the majority clearly agreed that, on the facts, no due process violation had occurred, the articulation of the constitutional test remained quite ambiguous:

The Due Process Clause of the Fourteenth Amendment, as interpreted in Brady, makes the good or bad faith of the State irrelevant when the State fails to disclose to the defendant material exculpatory evidence. But we think the Due Process Clause

\footnotetext{
95. 467 U.S. 479.

96. Brady v. Maryland, 373 U.S. 83 (1963).

97. Trombetta, 467 U.S. at $479-80$.

98. 488 U.S. 51 (1988).

99. Fluid samples from the boy's rectum and mouth were taken, as well as comparison samples of the boy's saliva, blood, and hair. Although the boy's underwear and T-shirt were collected, they were not refrigerated or frozen, and, subsequently, the fluids deteriorated. Samples of semen were also taken from the assailant but were also allowed to deteriorate. When these samples were ultimately tested, the results, though inconclusive, indicated that the assailant was a "nonsecretor" -that is, a male who does not secrete a blood type "marker" into other body fluids, such as semen. The accused was a secretor.

Furthermore, the boy had testified that the assailant's car had a loud muffler, that country music was playing on its radio, and that the car was started using a key. The accused and other defense witnesses testified that his car was inoperative on the night of the assault, but that when it was running, there was no noise, the radio did not work and the car could only be started with a screwdriver. When Youngblood was arrested, his car was seized, examined, and turned over to a wrecking company, which dismantled the car before he could view it. See id. at 71-72 \& n.9 (Blackmun, J., dissenting).
} 
requires a different result when we deal with the failure of the State to preserve evidentiary material of which no more can be said than that it could have been subjected to tests, the results of which might have exonerated the defendant... . We think that requiring a defendant to show bad faith on the part of the police both limits the extent of the police's obligation to preserve evidence to reasonable bounds and confines it to that class of cases ... in which the police themselves by their conduct indicate that the evidence could form a basis for exonerating the defendant. We therefore hold that unless a criminal defendant can show bad faith on the part of the police, failure to preserve potentially useful evidence does not constitute a denial of due process of law.

This passage could be construed as demanding a showing of bad faith as the exclusive grounds for relief, thus jettisoning altogether Trombetta's three-fold analysis. Alternatively, the Court could be stating that governmental culpability is a function of evidentiary materiality: The more significant the exculpatory value of the evidence, the lower the burden of proof of culpability.

Was the breath sample potentially more significant to Trombetta's defense of the drunk-driving charges than were the fluid traces on the victim's clothing in the sexual assault prosecution of Youngblood? If so, that might explain the imposition of the heavier "bad faith" burden in Youngblood. Unfortunately, that assessment of the relative materiality of evidence in these two cases is not convincing; to the contrary, testing the clothing for DNA evidence in Youngblood seems far more important to fundamental fairness than providing a breath sample for the defendant's independent analysis in Trombetta. ${ }^{101}$ Furthermore, both the concurring and dissenting opinions in Youngblood suggest that at least those four Justices believed that the majority had embraced bad faith as the sine qua non for relief in failure to collect and preserve cases. ${ }^{102}$

\section{IV}

\section{THE Duty To PRESERVE Forensic INTERVIEWS OF CHILD WITNESSES}

Constitutional arguments that there is a duty upon the state to preserve a forensic interview of a child witness will vary according to which one of three potentially applicable rules is considered controlling: (1) the failure of the state rises to the level of Youngblood's exclusive "bad faith" test; (2) the failure of the state violates the Youngblood-Trombetta balancing test; or (3) the failure of the state to videotape a forensic interview of a child constitutes a special category of misconduct for which the Due Process Clause provides redress.

100. Id. at $57-58$.

101. There is the possibility of a middle category of materiality that might be governed by some sort of balancing test or, in any event, in accordance with a less onerous standard than a showing of bad faith. In United States v. Agurs, 427 U.S. 97, 106, 110 (1976), the Court has acknowledged the existence of such a middle category, terming such evidence "clearly supportive" or "highly probative" of innocence.

102. Justice Stevens explained that he only concurred in the judgment because the majority opinion swept too broadly by embracing the bad faith standard: "In my opinion there may well be cases in which the defendant is unable to prove that the State acted in bad faith but in which the loss or destruction of evidence is nonetheless so critical to the defense as to make a criminal trial fundamentally unfair." Youngblood, 488 U.S. at 61 (Stevens, J., concurring). 
A. Possibilities of "Bad Faith"

At least twenty-two states and the District of Columbia have dutifully (and properly) interpreted Youngblood to require that a defendant show bad faith as the exclusive predicate for a denial of fundamental fairness in duty to preserve claims. ${ }^{103}$ What constitutes bad faith or good faith? There is no single encapsulation of this elusive concept, though the Court has adopted it as the measure of police accountability in several different contexts aside from these evidentiary access cases. ${ }^{104}$ Certainly, a knowing and deliberate violation of established constitutional rights owed an accused would constitute bad faith. ${ }^{105}$ Like withholding evidence, misleading an accused about its existence despite an inquiry or discovery request that puts the state on notice of the exculpatory value of the evidence has been characterized as bad faith. ${ }^{106}$ Similarly, losing or destroying evidence in violation of a statute requiring preservation, ${ }^{107}$ or after a court order, ${ }^{108}$ constitutes bad faith.

Deliberately destroying or hiding evidence ${ }^{109}$ having "apparently exculpatory value" under Brady would also clearly qualify as bad faith. ${ }^{110}$ The mishandling of evidence intended to be the subject of prosecution testimony at trial would be bad faith as well, as this is a trial strategy reflecting the state's own assessment of mate-

103. See United States v. Day, 697 A.2d 31, 35 (D.C. App. 1997); State v. Youngblood, 844 P.2d 1152, 1153 (Ariz. 1993) (on remand from the United States Supreme Court); Lee v. State, 942 S.W.2d 231, 235 (Ark. 1997); People v. Cooper, 809 P.2d 865, 886 (Cal. 1991); State v. Larrinaga, 569 So. 2d 911, 912-13 (Fla. Dist. Ct. App. 1990); People v. Blaylock, 723 N.E.2d 1233, 1236 (Ill. App. Ct. 2000); Nettles v. State, 565 N.E.2d 1064, 1067 (Ind. 1991); State v. Dulaney, 493 N.W.2d 787, 792 (Iowa 1992); State v. LaMae, 998 P.2d 106, 110-11 (Kan. 2000); Collins v. Commonwealth, 951 S.W.2d 569, 572 (Ky. 1997); State v. Schexnayder, 685 So. 2d 357, 365 (La. Ct. App. 1996); State v. Berkley, 567 A.2d 915, 918 (Me. 1989); Patterson v. State, 741 A.2d 1119, 1128 (Md. 1999); Richard v. State, 798 S.W.2d 468, 470-71 (Mo. Ct. App. 1990); State v. Castor, 599 N.W.2d 201, 214 (Neb. 1999); People v. Bridges, 584 N.Y.S.2d 360, 361 (N.Y. App. Div. 1992); State v. Robinson, 488 S.E.2d 174 (N.C. 1997); State v. Steffes, 500 N.W.2d 608, 613 (N.D. 1993); State v. Arguello, 502 N.W.2d 548, 550 (S.D. 1993); State v. Bakalov, 979 P.2d 799, 816 (Utah 1999); Park v. Commonwealth, 528 S.E.2d 172 (Va. App. 2000). Compare Commonwealth v. Deans, 610 A.2d 32 (Pa. 1992) (distinguishing Youngblood when state sought to use lost evidence to establish guilt) with Commonwealth v. Small, 741 A.2d 666 (Pa. 1999) (following Youngblood in denying claim based on allegedly lost notes of witnesses' preliminary statements).

104. See e.g., Illinois v. Krull, 480 U.S. 340, 349-53 (1987) (using an officer's good faith reliance on a procedural statute or ordinance, though invalid, to validate a search); United States v. Leon, 468 U.S. 897, 90405 (1984) (using an officer's good faith reliance on a warrant, though invalid, to validate a search); Michigan v. DeFillippo, 443 U.S. 31, 33-35 (1979) (using an officer's good faith reliance on a substantive criminal statute or ordinance, though unconstitutional, to validate an arrest); Franks v. Delaware, 438 U.S. 154, 155-56 (1978) (requiring a showing of bad faith as the predicate for obtaining subfacial review of a warrant); Wood v. Strickland, 420 U.S. 308, 322 (1975) (using good faith as the test in construing 42 U.S.C. $§ 1983$ claims against state officials for deprivation of constitutional rights while acting under color of state law).

105. In Franks, the Court equated bad faith with deliberate falsehoods or statements made with reckless disregard for the truth in sworn applications for search warrants, in violation of the defendant's Fourth Amendment right to be free of unreasonable searches and seizures. 438 U.S. at 154.

106. See United States v. Cooper, 983 F.2d 928, 931-32 (9th Cir. 1993); Stuart v. State, 907 P.2d 783, 793

(Idaho 1995); People v. Coleman, 718 N.E.2d 1074, 1077 (Ill. App. Ct. 1999).

107. See, e.g., N.C. GEN. STAT. §15-11.1(a) (2000).

108. See, e.g., State v. Blackwell, 537 S.E.2d 457, 463 (Ga. Ct. App. 2000).

109. See McCune v. City of Grand Rapids, 842 F.2d 903, 907 (6th Cir. 1988).

110. Richard v. State, 798 S.W.2d 468, 471 (Mo. Ct. App. 1990). 
riality and demonstrates per se the highly material nature of the evidence. ${ }^{111}$ Engineering a procedure that was likely to produce misleading evidence was found to be a violation of due process, though the court did not use the term "bad faith."112 Bad faith is also established when the police threaten or coerce witnesses into developing false evidence. ${ }^{113}$ Continued use of particular experts to evaluate evidence despite knowledge of their unreliability may constitute bad faith. ${ }^{114}$

Certainly, as the Court noted in Youngblood, ${ }^{115}$ we can infer bad faith-that the police may be aware of the exculpatory value of the evidence-when they deviate from standard procedures of handling evidence. ${ }^{116}$ Many Supreme Court decisions indicate that following standard operating procedure is a hallmark of governmental good faith and will defeat any assertions to the contrary. ${ }^{117}$

Bad faith is more easily assessed when some police action is in the spotlight. In contrast, the most problematic type of investigative behaviors to characterize is inaction or sins of omission: failing to interview witnesses, ignoring contrary hypotheses, displaying indifference to physical evidence, and the like. Suppose, for example, that an armed robbery occurs in which the assailant fires two bullets but misses the storeowner. The assailant flees, and a suspect detained in the vicinity is positively identified by the storeowner. The bullets are retrieved from the walls of the store but then discarded by the police. Can bad faith be inferred from the fact that the officers knew or should have realized the probative value of the bullets to prove or exonerate the suspect? Would the failure to subject the bullets to ballistic testing or at least preserve them for such testing by the defendant constitute a violation of Youngblood? Some lower courts have found bad faith reflected in such sloppy police practices, ${ }^{118}$ although a very similar claim was rejected in

111. In United States v. Belcher, 762 F. Supp. 666 (W.D. Va. 1991), a prosecution for possession of drugs, the police destroyed plants taken from the defendant although they offered testimony that the plants were marijuana. Thus, the court held that the Youngblood caveat did not apply. Id. at 672 .

112. See Foster v. California, 394 U.S. 440, 442-43 (1969) (discussing unfair lineup procedures).

113. See, e.g., Ex parte Brandley, 781 S.W.2d 886, 892-94 (Tex. Crim. App. 1989).

114. See e.g., Jones v. State, 761 So. 2d 907, 910 (Miss. Ct. App. 2000) (clarifying in dictum that, in support of his bad faith claim, the defendant had not presented any claim that previous tests done by the lab for the state were untrustworthy).

115. 488 U.S. at 58.

116. "[T]he interests of justice most clearly require [redress in] those cases in which the police themselves by their conduct indicate that the evidence could form a basis for exonerating the defendant." Id.

117. In both Killian and Trombetta, the Court yoked good faith and established conventions: "In failing to preserve breath samples for respondents, the officers here were acting in good faith and in accord with their normal practice."” California v. Trombetta, 467 U.S. 479, 488 (quoting Killian v. United States, 368 U.S. 231, 242 (1961)). In Colorado v. Bertine, in approving an inventory search, the Court thought it significant that there had been "no showing that the police, who were following standard procedures, acted in bad faith or for the sole purpose of investigation." 479 U.S. 367, 372 (1987). See also United States v. Watkins, 188 F.3d 520 (10th Cir. 1999) (finding no bad faith where the defense failed to support its argument that the agent's destruction of witness interview notes violated DEA policy because it offered no proof of that policy at trial).

118. See, e.g., Brandley, 781 S.W.2d at 894. The following anecdote may be of the penultimate police failure. Police officers in New Orleans who were investigating the slaying of a man in front of his home failed to find the body of a teenager who was also a homicide victim. The body was lying "just yards away and went unnoticed for hours until a relative found it." Police overlook body; error prompts probe, THE ADVOCATE (Baton Rouge, La.), Aug. 23, 2001, at 7-B. 
Youngblood. Is it bad faith when the government fails to provide the law enforcement agency with the proper equipment to preserve the evidence or to provide them with a sufficient budget for adequate forensic tests? Unresolved issues of this type abound.

Even if the sterner "bad faith" showing constitutes the required burden of proof, fundamental fairness claims based on the failure to videotape a forensic interview of a child may rise to such a level. The failure to record a procedure scheduled and set in motion for the precise purpose of trial preparation involves deliberate prosecutorial involvement far beyond every fact pattern so far considered and rejected by the Court.

\section{B. The Balancing Test Weighing Motive and Materiality}

The depth of resistance to the "flat bad faith requirement of Youngblood" manifested by the substantial number of states that refuse to follow it. ${ }^{120}$ There are at least twenty-one states that now use a combination of Trombetta ${ }^{121}$ and Youngblood or have announced a different test under the aegis of their state constitutions. ${ }^{122}$ The bad faith standard has been rejected by these states because it is quite amorphous and requires the analysis of the motivation of the officers, a far murkier assessment of their intent than an evaluation of the impact of the lack of the evidence upon the trial of the accused. More importantly, and rather oddly, it shifts review from the heart of the due process guarantee-the impact upon the fair trial right - to the reasons for officers' dereliction. For the accused facing prosecution, whether a critical sample of blood was purposely lost or negligently lost pales in contrast to the fact of the loss. The role it could have played in securing an acquittal is all that matters. Furthermore, as Chief Justice Feldman cautioned when Youngblood ${ }^{123}$ was remanded to his court:

Regardless of whether important evidence is exculpatory or inculpatory, good public policy requires that the police use care in preserving it. Instead of requiring a defendant to prove something as nebulous and subjective as a police officer's bad

119. Gurley v. State, 639 So. 2d 557, 566 (Ala. Crim. App. 1993).

120. One author attributes the lower courts' lack of adherence to Youngblood's exclusive bad faith test to a failure of understanding. See Matthew H. Lembke, Note, The Role of Police Culpability in Leon and Youngblood, 76 VA. L. REV. 1213, 1222 n.55. It seems far more likely when so many courts do not follow Supreme Court precedent that they are consciously resisting its lead.

121. 467 U.S. 479 (1984).

122. See Grimsley v. State, 678 So. 2d 1197, 1203-05 (Ala. Crim. App. 1996); Thorne v. Department of Pub. Safety, 774 P.2d 1326, 1331 (Alaska 1989); People v. Eagen, 892 P.2d 426, 428-29 (Colo. Ct. App. 1994); State v. Morales, 657 A.2d 585, 589 (Conn. 1995); State v. Blackwell, 537 S.E.2d 457, 462 (Ga. Ct. App. 2000); State v. Matafeo, 787 P.2d 671, 673 (Haw. 1990); State v. Fain, 774 P.2d 252, 257-66 (Idaho 1989); Commonwealth v. Henderson, 582 N.E.2d 496, 497 (Mass. 1991); Jones v. State, 761 So. 2d 907, 90910 (Miss. Ct. App. 2000); State v. Brown, 982 P.2d 468, $472-73$ (Mont. 1999); Cook v. State, 953 P.2d 712, 714-16 (Nev. 1998); State v. Smagula, 578 A.2d 1215 (N.H. 1990); State v. Joncas, 554 A.2d 841, 843 (N.H. 1989); State v. Montijo, 727 A.2d 533, 533-38 (N.J. Super. Ct. Law Div. 1998); State v. Chouinard, 634 P.2d 680 (N.M. 1981), cert. denied 456 U.S. 930 (1982), cited with approval by State v. Ware, 881 P.2d 679, 682 (N.M. 1994); State v. McCoy, 998 P.2d 709, 714 (Or. Ct. App. 2000); Childs v. State, 988 P.2d 898, 901 (Okla. 1999); State v. Campbell, 691 A.2d 564, 569-70 (R.I. 1997); State v. Mabe, 412 S.E.2d 386, 388-89 (S.C. 1991); State v. Delisle, 648 A.2d 632, 642-43 (Vt. 1994); State v. Paynter, 526 S.E.2d 43, 54 (W. Va. 1999); Young v. State, 849 P.2d 754, 764-65 (Wyo. 1993).

123. 488 U.S. 51 (1988). 
faith, we should encourage due care. Today's holding invites bad police work, so long as the government does not act in bad faith, whatever that is. ${ }^{124}$

Under the Trombetta-Youngblood combination test for a due process violation, the defendant must prove the following: first, that the missing evidence is unique and nonreplicable; second, that it is highly material to the defense; and third, that the police knew or should have known of its value, that is, that its exculpatory value was apparent, so that the police may be said to have acted in bad faith.

Proof of the uniqueness factor is straightforward. For example, retesting a breath sample or subjecting any other piece of physical evidence to laboratory analysis is not the only way an accused can dispute the reliability of the state's testing. In Trombetta, Justice Marshall noted that the defendant had a statutory right to inspect the Intoxilyzer machine, check its calibration reports, investigate known sources of distortion, and cross-examine the machine operator for possible confession of improper practices. ${ }^{125}$ In contrast, early in the investigation, when the child's remembered account is likely to be at the height of its vibrancy, the state enjoys the unilateral advantage of evaluating the child's credibility. Such an interview is a unique encounter, a nonreplicable interaction between two human beings. Without a verbatim record, there is no way to test the validity of the claim that the forensic interview of a child was neutrally conducted and faithfully recalled:

Summaries of unrecorded interviews are subject to any number of distortions. It is a well documented fact in the psycholinguistic literature that when asked to recall conversations, most adults may recall the gist, but they cannot recall the exact words used, nor the sequences of interactions between speakers. ... [I]nterview information of the most critical kind is lost when a verbatim recording is not made. [As one prosecution expert conceded], "Sometimes you take notes, you write down the answer, but not necessarily write down verbatim what all your questions are." Of course, the number of questions, their wording, their nature, and the tone of the interviewer questions are precisely what is needed to evaluate the effect of the interviewers' questions on the children. ... This linguistic information rapidly fades from memory, minutes after the interactions have occurred. ${ }^{126}$

Furthermore, in contrast with other types of offenses, the only source of evidence in child sexual abuse cases is typically the accusation of the child. ${ }^{127}$ The forensic interview thus meets the first prong of the Trombetta-Youngblood test: It is clearly

124. State v. Youngblood, 844 P.2d 1152, 1164 (Ariz. 1993) (Feldman, C.J., concurring in part and dissenting in part).

125. See Trombetta, 467 U.S. at 490.

126. Pro Se Appellant's Brief at 7-8, State v. Doggett, No. 15014-3-III, 1998 Wash. App. LEXIS 947 (Wash. Ct. App. June 10, 1998). This Brief was ghost-written by Robert Rosenthal, New York City, who served as appellate counsel and successfully pursued appeals on behalf of Kelly Michaels (State v. Michaels, 625 A.2d 489 (N.J. Super. Ct. App. Div. 1993), aff'd, 642 A.2d 1372 (N.J. 1994)), Grant Snowden (Snowden v. Singletary, 135 F.3d 732 (11th Cir. App. 1998)), and other high-profile alleged child abusers. For an account of some of Rosenthal's cases, see Trevor Armbrister, I'm Not Guilty, READER's DigEST, May 1, 1999, at 119.

127. "Child abuse is one of the most difficult crimes to detect and prosecute, in large part because there often are no witnesses except the victim." Pennsylvania v. Ritchie, 480 U.S. 39, 60 (1987). 
unique evidence, and there is no comparable evidence reasonably available to the person accused by the child.

Hand-in-hand with the requirement that the missing evidence be unique and irreplaceable is the requirement that the evidence have significant exculpatory value. How does one prove that the evidence would have been valuable to the defense when it can no longer be reviewed? In Trombetta, the Court noted that categorical evidence of the accuracy of the testing process, that is, the Intoxilyzer's measurement of samples, could supply the missing predicate. ${ }^{128}$ Since that machine was highly accurate, was periodically and frequently checked for malfunction, and had rare false positives that were caused by known interferences that could be investigated and disproved in a particular case, the Court found that the evidence of test results was highly reliable and thereby concluded that the missing breath samples lacked significant exculpatory value. ${ }^{129}$ In contrast, the likelihood of interviewer error is well established, and there are substantial reliability risks in receiving hearsay reports of scattered children's assertions made during an interview. ${ }^{130}$

The third requirement of "bad faith" can be inferred from deviation from standard practice or from an independent showing that the police knew or should have known that preservation of the evidence was essential to a fair trial. The suggestibility of young children has become well known. High-profile child sexual abuse prosecutions have heightened public, and more so police, awareness of the suggestibility of children. In addition to appellate decisions, ${ }^{131}$ newspapers, ${ }^{132}$ magazines, ${ }^{133}$ and television documentaries ${ }^{134}$ have given sensationalized coverage to prosecutions that foundered on poor interviewing of child witnesses. Every state, it seems, has produced its own disaster: the McMartin preschool case in California; the Wenatchee, Washington sex-ring cases; the Jordan, Minnesota sexual abuse investigation by the Attorney General; the Fells Acres Day School case in Massachusetts; and the Country Walk DayCare Center case in Florida, to recall only a few. ${ }^{135}$ As a Michigan State Police detective recalled, "I've been in forty of fifty states. Everyone is concerned with child abuse. Even in rural southwestern Indiana, they ask, 'How can we make our investigatory system work better in these types of cases?' Even in a rural area they are seeing these cases." ${ }^{136}$

In sum, because if Trombetta is deemed to have survived Youngblood, then a strong argument can be made that uniqueness and nonreplicability, high material-

\footnotetext{
128. Trombetta, 467 U.S. at 489.

129. Id.

130. See supra text accompanying notes 21-24.

131. See, e.g., State v. Michaels, 625 A.2d 489 (N.J. Super. Ct. App. Div. 1993), aff'd, 642 A.2d 1372 (N.J. 1994).

132. See, e.g., Dorothy Rabinowitz, Verdict in Wenatchee, WALL ST. J., Dec. 15, 1995, at A14; Dorothy Rabinowitz, Wenatchee: A True Story, WALL ST. J., Sept. 29, 1995, at A14.

133. See, e.g., Armbrister, supra note 126.

134. See, e.g., Innocence Betrayed (PBS documentary broadcast, Apr. 23, 1991).

135. See CECI \& BRUCK, supra note 27, and MCGOUGH, supra note 6, for other examples and citations.

136. Mark E. Rust, The Nightmare is Real, 14 STUD. LAw. 12, 15-16 (1986) (quoting Det. Jack Shepherd).
} 
ity, and inferable bad faith are all characteristics of an investigative interview of a child under evaluation as a critical trial witness.

\section{Special Obligation When the State is Creating Forensic Evidence}

It is possible that, sub silentio in its Trombetta and Youngblood opinions, the Court was distinguishing between instances in which the police themselves create evidence to be used at trial, such as Trombetta's forensic test of physical evidence, and instances in which the police play a much more passive role, such as Youngblood's bailment of existing evidence. Certainly it seems sensible that there is a higher obligation imposed upon the state when it takes advantage of its superior resources and pretrial control of the investigation to produce or prepare testimonial evidence for trial than when it simply provides storage.

There is some inkling of the importance of this notion of the state's role in actively procuring critical evidence in the Court's 1967 Wade-Gilbert-Stovall trilogy involving the staging of a forensic lineup or showup for identification. ${ }^{137}$ Though a quarter-century before Trombetta and Youngblood, the Court's factoring process in those cases is remarkably current. The Court held that, where there was a "grave potential for prejudice, intentional or not, in the pretrial lineup, which may not be capable of reconstruction at trial," and where the risk of pretrial misidentification may be later irremediable, constitutional safeguards are required. ${ }^{138}$ That passage can now be translated into the Trombetta-Youngblood formula: Where there is great materiality of unique, nonreplicable evidence, there is bad faith and, hence, a violation of due process, if the prosecutorial team fails to preserve it for disclosure to the accused and for review at trial.

Like the lineup, the forensic interview of a child is instigated, organized, and orchestrated by the state for use at trial. There are undeniable parallels between the state's role in constructing a lineup and conducting a forensic interview with a child victim. Furthermore, the potential unreliability of investigative interviewing is clearly analogous to the notorious unreliability of eyewitness identification which the Court acknowledged in Wade. As the Wade Court observed, "[a] major factor contributing to the high incidence of miscarriage of justice from mistaken identification has been the degree of suggestion inherent" in the encounter. ${ }^{139}$ Suggestion in constructing a lineup or showup can be created "intentionally or unintentionally in many subtle ways." ${ }^{140}$ Identification is a critical issue in any prosecution and, "in practice, the issue of identity [and the elements of the crime] may (in the absence of other relevant evidence) for all practical purposes be de-

137. See United States v. Wade, 388 U.S. 218 (1967); Gilbert v. California, 388 U.S. 263 (1967); Stovall v. Denno, 388 U.S. 293 (1967).

138. Wade, 388 U.S. at 236-38. Wade and Gilbert were decided on right-to-counsel claims under the Sixth and Fourteenth Amendments; Stovall involved a pure due process claim since the Court held that its decisions in Wade and Gilbert were not to be applied retroactively. See Stovall, 388 U.S. at 297-99.

139. Wade, 388 U.S. at 228.

140. Id. at 229. The Court often uses the explanation that officers are "engaged in the often competitive enterprise of ferreting out crime.” Johnson v. United States, 333 U.S. 10, 13-14 (1948). 
termined there and then, before the trial." ${ }^{, 141}$ As with constructing lineups, there are possibilities of skewing the reliability of the child's account during an investigative interview. ${ }^{142}$ Even if most investigators do not intentionally subvert the accuracy of a child's memories, obtaining detailed and reliable information from a child is a much more delicate task, with a higher risk of contamination, than setting up an identification lineup. ${ }^{143}$

And, finally, as the Court underscored in Wade, replication of the lineup evidence may be impossible: "[T]he accused's inability effectively to reconstruct at trial any unfairness that occurred at the lineup may deprive him of his only opportunity meaningfully to attack the credibility of the witness' courtroom identification." ${ }^{144}$ Similarly, as has been discussed previously, without a videotape it is impossible to review and assess the impact of the interviewer's role during the twists and turns of a child's disclosures.

To redress the grave potential of the production of unreliable and undiscoverable identification evidence from a lineup, the Wade Court required that counsel be present for any confrontation involving a formally accused defendant. ${ }^{145}$ If counsel were not provided, the lineup identification evidence could not be used by the state to convict the accused. ${ }^{146}$ Subsequently, the Court decided United States v. $A s h{ }^{147}$ In that case, the Court held that, if a photographic array was used for identification by the victim, counsel neither need be provided nor present. ${ }^{148}$ The photographic record of the "line-up" served to memorialize the identification task and to enable defense counsel to reconstruct the event and thus have a fair opportunity to impeach the witness's identification. ${ }^{149}$

141. Wade, 388 U.S. at 229.

142. Perhaps the most vivid example comes from a forensic interview conducted in Sweden. A nineyear-old girl had been kidnapped by a man and was held prisoner for a couple of days before she was rescued. There was no doubt that it was originally a kidnapping, but could she have not run away during the two days? The defense counsel, who was listening to the interview, requested the policeman-interrogator to ask the child if the accused was present all the time, and if she could not have run away. The policeman immediately said, "Oh hell, a little girl like that ... but of course I'll ask." The policeman went back to the room and asked the girl, "Was the man present all the time?" She said, "No, he went out and chopped some wood, and he went shopping." "Could you then have run away?" There was a silence, and then the policeman said, "Or were you really too scared to go anywhere?" And the child said, "Yes." Defense counsel would have asked the question in a different way. Eva Smith, How to Deal with Children's Evidence, in Children's Evidence in Legal PRoceEdings: An InTERnATIONAL PERSPECTIVE 17, 23 (J.R. Spencer et al. eds., 1989).

143. See MCGough, supra note 6.

144. Wade, 388 U.S. at 231-32.

145. See id. at 236-38. Of course, immediately after Wade, the Court soon began chipping away at the force of its pronouncement. If lineup evidence outside the presence of counsel was inherently and predictably unreliable, then why should any accused individual, whether indicted or simply arrested on probable cause as a suspect, be denied the presence of counsel? Nonetheless, five years later, in Kirby v. Illinois, 406 U.S. 682 (1972), the Court limited Wade's broad right of counsel to only those defendants who have been charged by indictment, preliminary hearing or other formal accusation. See id. at 690-91.

146. Wade, 388 U.S. at 236-37.

147. 413 U.S. 300 (1973).

148. See id. at 300-01.

149. Thus, there was no violation of the right of counsel if the defendant's lawyer was not present when the photographs were presented to the witness. In the mind's eye of the Rehnquist Court, concerns about preventing suggestibility were eclipsed by the sole requirement of preparing for adequate cross- 
Furthermore, and rather remarkably, the Rehnquist Court has recently fanned a few flickers of life into due process claims. In County of Sacramento v. Lewis, ${ }^{150}$ the Court revived Rochin v. California ${ }^{151}$ for the proposition that substantive due process extends to citizens accused of crimes. Due process is violated, observed the Court, when officers act with "intent to harm suspects physically or to worsen their legal plight." 152

In sum, a forensic interview of a child is so fraught with the potential for distortion by the interviewer, both as to the accusation of a crime and to the identification of the perpetrator, that there is a substantial risk of irremediable mistake and of an unfair trial if the interview is not recorded and made available to the defense in advance of trial. The Wade-Ash jurisprudence chain supports the constitutional necessity for an accurate, reconstructible record. In short, this requires a videotape of any forensic interview of a child victim. Idaho $v$. Wright does not foreclose the constitutional inquiry; as the Court there acknowledged, reasonably welltrained members of the prosecutorial team should know of the critical importance of preserving a record of any child witness's interview. ${ }^{153}$ A failure to record any staged encounter reflects an "intent to worsen the plight" of the accused, thus justifying the relief promised by the Due Process Clause.

\section{The Small World of Appellate Videotaping Decisions}

There is no appellate decision that raises the constitutional issue of the prosecution's failure to videotape a forensic interview with a child victim, although there are several decisions that pivot on the prosecution's failure to preserve the videotape. ${ }^{154}$ In addition to the two cases previously discussed, the Tennessee Su-

examination-equipping counsel to reconstruct the pretrial event and defend against it at trial. In Foster $v$. California, 394 U.S. 440 (1969), however, the Court preserved the potential for a violation of due process claim to redress egregious instances of police suggestiveness. See id. at 443-44.

150. 523 U.S. 833 (1998). Lewis involved a 42 U.S.C. $\$ 1983$ claim for damages stemming from a highspeed automobile chase.

151. 342 U.S. 165 (1952).

152. Lewis, 523 U.S. at 854.

153. 497 U.S. 805 (1990).

154. Schaal v. Gammon, 233 F.3d 1103 (8th Cir. 2000), is an atypical case in which the prosecution sought to introduce a forensic interview, albeit one that was a highly manipulated encounter, conducted by a psychologist with a seven-year-old who alleged rape by the accused. The Court of Appeals affirmed a district court's finding that the court committed error in receiving the tape into evidence pursuant to a special Missouri videotaped children's interview hearsay exception statute. Id. at 1104 . The record revealed that the child was never put under oath, and her mother, who was antagonistic to the accused, was present at all times. In addition, the Court noted:

The reliability of the child's statements is also affected by the relationship of the psychologist who conducted the videotaped interview with the child and her mother. The child and the psychologist met weekly for counseling sessions during the four months preceding the videotaped interview, including practice questioning sessions. The record also reveals that the child's mother was a patient of the same psychologist [for four years] . . . At one point during the interview, the psychologist stopped the videotape, took a break, reviewed the tape with the child, and resumed taping. The psychologist ultimately recorded two interviews of the child, taping over the first version with the second, thus selecting a version that achieved the desired effect and destroying one that apparently did not.

Id. at 1108 . 
preme Court's opinion in State v. Ballard ${ }^{155}$ and the Supreme Court's decision in Idaho $v$. Wright, ${ }^{156}$ a handful of other cases has raised the issue of a missing videotape of a child victim's interview. ${ }^{157}$

In a Colorado case, Morgan v. Gertz, ${ }^{158}$ a police detective interviewed a sevenyear-old girl who, according to her biological father, had possibly been sexually abused by her stepfather. At this interview, the child "gave no indication she had been the victim of sexual abuse." ${ }^{159}$ The detective put the tape in her desk and closed the case, with advice to the father that he should seek therapy for his daughter. ${ }^{160}$ About six weeks later, the father again contacted the police, this time to report that his daughter had provided specific details of the abuse. ${ }^{161}$ The detective scheduled a second interview and, when she could not locate a blank videotape, she decided to reuse the videotape she had, recording over and erasing all but remnants of the previous interview. ${ }^{162}$ At the second interview, the child alleged that she had been sexually assaulted by her stepfather on two occasions some six months before. ${ }^{163}$ Finding that the government misconduct had been "wilful and egregious" in destroying exculpatory evidence, and that there was no alternative method for the defendant to reconstruct what had transpired during the "crucial initial interview," the trial court granted a motion for a directed verdict of acquittal. ${ }^{164}$

The situation in State v. Ste. Marie reinforces the hazards of interviewing a child victim and the necessity for a record of the exchange. ${ }^{165}$ The forensic interviews of four preschoolers who complained of a neighbor's sexual assaults were conducted by a detective and were videotaped. ${ }^{166}$ After reviewing the tapes, an assistant district attorney allegedly commented that the detective's methods were improper, inappropriate, and suggestive, and that therefore the accusation was unreliable. ${ }^{167}$ The investigation went forward, however, and the children were re-

155. 855 S.W.2d 557 (Tenn. 1993). See also supra text accompanying notes 2-5.

156. 497 U.S. 805 (1990). See also supra text accompanying notes 90-94.

157. The truthfulness of young children's sexual abuse allegations was the heart of the case in the Florida prosecution of policeman Wayne Snowden, but the reversible error seized upon by the reviewing court was the state's use of an expert to vouch for the victim's credibility. See Snowden v. Singletary, 135 F.3d 732

(11th Cir. 1998), rev'g Snowden v. State, 537 So. 2d 1383 (Fla. Dist. Ct. App. 1989)).

158. 166 F.3d 1307 (10th Cir. 1999).

159. Id. at 1308 .

160. Id. at 1307.

161. Id.

162. Id

163. Id.

164. See id. at 1309. This decision is reported by the Tenth Circuit Court of Appeals in its denial of the defendant's $\S 1983$ action seeking damages for the violation of his civil rights. The court noted that, when all criminal charges have been dismissed prior to trial, no cause of action exists under 42 U.S.C. $\S 1983$ for denial of a fair trial. $I d$. at 1310.

165. 704 So. 2d 430 (La. Ct. App. 1997), rev'd and remanded, 723 So. 2d 407 (La. 1998), 741 So. 2d 823

(La. Ct. App. 1999), rev'd and remanded, 770 So. 2d 315 (La. 2000).

166. Ste. Marie, 770 So.2d at 317.

167. Ste. Marie, 741 So.2d at 827. 
ferred to a licensed clinical social worker. ${ }^{168}$ After a discovery request for the tape, ${ }^{169}$ the state reported on the day of trial that it was lost, although the state offered an audiotape of the interview. The trial court denied the motion for a continuance and forced the defendant to trial. The missing videotape turned out to be an important benchmark against which to compare other versions of the accusation. One of the children repeated her accusation but gave inconsistent details to her therapist and also later at trial. ${ }^{170}$ A neighbor who was present at the initial informal interrogation by the police testified about disclosures then made by the child that differed from the later account preserved in the videotaped interview. ${ }^{171}$ Fourth and fifth versions, hearsay reports of the child's statements, were offered in testimony by two of the children's mothers. Finally, the child testified on crossexamination about a practice interview conducted by the prosecutor. ${ }^{172}$

Ste. Marie was a typical sexual abuse prosecution with multiple investigatory adult-child exchanges about the child's experiences. Indeed, in addition to casual exchanges within the family, most child victims, on average, are interviewed at least a dozen times during the course of a criminal investigation. ${ }^{173}$ With so many possibilities for contamination, the videotape of the forensic interview is the benchmark that is essential for tracing and then unraveling the child's independent reminiscences from the suggested gloss or misinterpretations of well-meaning adults.

There simply is no substitute for a videotaped record of a forensic interview of a child. No case illustrates that better than the naïve opinion of a Florida District Court of Appeal in State v. Larrinaga. ${ }^{174}$ A detective interviewed two children, apparently together, in a "30-40 minute videotaped interview." 175 When both children denied that the defendant had abused them, the investigation was closed, and the videotape was erased a year later. The appellate court found no violation of due process, citing the fact that the children were prepared to testify that, in the initial forensic interview, they had denied any abuse; ${ }^{176}$ furthermore, the court noted that the detective also would testify that the children did not confirm any

168. See id. at 824-25 (discussing the subsequent conduct of the investigation and the children's consultation with a licensed clinical social worker).

169. Defense counsel was permitted to view the videotape twice before its loss, once shortly after the defendant's arrest, and later when it was shown at the preliminary examination. See Ste. Marie, 770 So.2d at 317. The Louisiana Supreme Court ultimately found no due process violation, because the defendant expressly absolved the state of any bad faith in the loss of the tape and thus had not met the burden imposed by Youngblood. Arizona v. Youngblood, 488 U.S. 51, 58 (1988); Ste. Marie, 770 So.2d at 318. In addition, the Court noted that the defense had not been compromised by the loss, because the state had freely disclosed the contents of the videotape to defense counsel and had provided the audiotape, both of which were used with some effectiveness in cross-examination at trial. See id.

170. Ste. Marie, 741 So. $2 \mathrm{~d}$ at $826-27$.

171. Id. at 827 .

172. Id. at 826 .

173. See WhitCOMB ET AL., supra note 29, at 99.

174. 569 So.2d 911 (Fla. Dist. Ct. App. 1990).

175. See id. at 912. The dangers of "cross-pollination" resulting from joint interviews with alleged victims is well documented. See, e.g., OfFice of THE AtTORNEY-GENERAl Of MinNESOTA, Hubert H. HUMPHREY III, ATTORNEY-GENERAL, REPORT ON SCOTT COUNTY INVESTIGATIONS 11-12 (1985).

176. Larrinaga, 569 So.2d at 913. 
abuse in that interview, although he was "unable to recall the specific details of his interview with the children." ${ }^{177}$

As previously noted, it is not surprising that the adult interviewer could only remember the gist of the conversation, but it is precisely the specific details that make all the difference to a fair trial and a fair assessment of the truth of the original denial as well as its later recantation. Although dismissal of the charges is not always the appropriate remedy for destruction of evidence, a summary or even a stipulation that no accusation was made is a clearly inadequate remedy in these cases involving lost or destroyed videotapes of forensic interviews with children.

\section{$\mathrm{V}$ \\ CONCLUSION}

Doubts about the reliability of a child's accusation can ultimately destroy confidence in any verdict and in the fundamental fairness of the trial. ${ }^{178}$ Consequently, whatever justification may have once existed for ignoring the special needs and fragility of child witnesses, interviewing them like adult witnesses is no longer "good enough for government work." If legislatures fail to impose a statutory requirement for videotaping of forensic interviews of children, courts should acknowledge the constitutional duty of the government to preserve that critical evidence.

177. Id.

178. See Kyles v. Whitley, 514 U.S. 419, 439 (1995); United States v. Bagley, 473 U.S. 667, 682 (1985). 